\title{
Perception, Gender and Social Media Usage by Students of Tertiary Institutions in Delta State, Nigeria
}

\author{
Emmanuel Ufuophu-Biri, $\mathrm{PhD}$ \\ Department of Mass Communication, Faculty of the Social Sciences, Delta State University, Abraka, Nigeria
}

\begin{abstract}
Bibliographical Notes
Dr Emmanuel Ufuophu-Biri is an Associate Professor of Mass Communication and Journalism at Delta State University, Abraka, Nigeria; and Director, Pre - Degree Programme in same University. He holds PhD in Communication Arts, MA (Distinction) Mass Communication, Master's Degree in Industrial and Labour Relations, B.A. Mass Communication, Diploma and Advanced Diploma in Journalism, Certificate in TV Production and Certificate in Digital Humanities, Brown University, Providence, USA. He is an Alumnus of the Brown University International Advanced Research Institute, Providence, USA and the USA International Visitors' Leadership Program (IVLP), USA. He is interested in print and broadcast journalism, development communication and digital media.
\end{abstract}

DOI: $10.7176 / \mathrm{NMMC} / 89-02$

Publication date: April $30^{\text {th }} 2020$

\begin{abstract}
Studies have indicated increased use of the social media by students for varied purposes. The students also have different perception of the social media. However, such studies are scanty with reference to students in the higher institutions of learning in Delta State, Nigeria. Therefore, this study examined the perception and gender of students of tertiary institutions of learning in Delta State, Nigeria and their pattern of the social media usage. The study was guided by Uses and Gratification theory, which emphasizes why people use the media and the gratification they derive from the usage. Questionnaire was used to collect data from 5382 respondents across six institutions. Simple random technique was used to select the institutions. The individual respondents were subsequently selected randomly. The data were analyzed with descriptive and inferential statistics. Hypotheses were tested at $\mathrm{P}<0.05$ level of significance. The finding showed that the students use the social media primarily for 14 different purposes. They use only $4.38 \%$ of the 253 social media. They use social media frequently and they have positive perception of them; there is significant relationship between the students' perception and their usage of the social media. There is no significant relationship between gender and the students' usage of the social media. The study recommends that the authorities of the institutions should formulate and implement productive ICT policies and enlighten the students on how to use the social media for positive and productive purposes.
\end{abstract}

Keywords: Social media, Perception, Usage pattern; Institutions of higher learning, Mainstream Media

\subsection{Introduction}

The social media are basically Internet social networking sites that connect people together for a variety of purposes. The purposes range from friendship, chatting, courtship, commerce, education to mass communication. The social network/media which started in 1999 with HR.com have grown to over 253 social media sites globally. The social media include Facebook, Youtube, Bebo, MySpace, Flickr and Twitter, etc. Kaplan and Haenlein (2010) regard the social media as a group of Internet-based applications that build on the ideological and technological foundations of Web 2.0 and that allow the creation and exchange of user-generated content. The social media are tools used for information dissemination, especially among friends and colleagues who are not media practitioners but are connected through the Internet. (Eid \& Al-Jabri 2016, Ford \& Ravansari, 2017). Dedanne emphasizes that the death of the Pop Star, Michael Jackson, in June 2009 was first announced and made known by users of the social media. In Nigeria the major media houses use the social media. People use them to get new friends; find old friends and relatives; advertise themselves online; react to mass media publications; post stories and opinions; chat with friends; mobilize the masses for mass actions; advertise products; send political campaign messages; get information about current occurrences; and for opinion survey. Many of these users are students Junco (2011) observes that many students use the social media for purposes such as interacting with friends, studying, and status conferral among other purposes.

However, the operation of the social media has met with a lot of complaints, especially in the area of accuracy and credibility; falsehood; online promiscuity/prostitution; blackmail, anonymity; forgery; online fraud (419); and impersonation. Different people thus have different perception of the social media and use them for different purposes - some virtuous and others vicious. There is belief that students use the social media negatively and devote much time to them unnecessarily. 


\subsection{Statement of Problem}

The social media have been adopted by different people for different purposes. Some of the purposes for which the social media are used are noble while others are regarded as vicious. Some authorities such Dedanne (2009) Leach (2009) Hu, Manikonda, Kambhampati (2014). Tsai, Chang, Chang, Chang (2017) believe that the youths, especially students of institution of higher learning use the social media mainly for both positive and negative purposes. He postulates that many students have negative perception of social media and use them basically for negative purposes. This situation may also apply to the students of the higher institutions of learning in Delta State.

For instance, Adomi (2006) found that students of universities in Nigeria use the social media for different purposes, both positive and negative, and many of them may have wrong perception of the social media. Salaam (2003) fears that the proportion of students of Nigerian universities who uses the so Internet is inadequate, thus many of them may not be benefitting from advantages of the social media. This may not be a healthy situation considering the important role of the social media in modern society. Such perception and usage would amount to deviation from fundamental philosophical foundation of the social media. The followings therefore, are the objectives of the study.

\subsubsection{Objectives of the Study}

The objectives of the study are to determine:

i. the primary purposes for which the students use the social media;

ii. $\quad$ how many hours spent daily by the students in using the social media;

iii. the students perception of the social media;

iv. the relationship between gender and the students' usage of the social media; and

v. the relationship between the students' perception and their use of social media

\subsubsection{Research Questions}

The following research questions and hypotheses were therefore formulated to guide the study.

i. What are the primary purposes for which the students use the social media?

ii. What are the preferred social media used by the students?

iii. How many hours spent daily by the students in using the social media?

iv. What is the students' perception of the social media?

\subsubsection{Hypotheses}

The following hypotheses were formulated to address the objectives of this study:

i. There is no significant relationship between gender and the students' usage of the social media.

ii. There is no significant relationship between the students' perception and their use of Social media

\subsection{Theoretical Framework}

The Uses and Gratification theory which explains reasons which explains which explains why people use the media served as the theoretical guide. Blumler and Katz (1974) who propounded the theory, explain that the theory is concerned with who uses the media; how he uses the media and the gratification he gets or intends to get from using the mass media. The theory suggests that the user of the media plays significant and active role in the selection of media to use, the content of the media to be used and how to use them. The theory posits that the media users seek out the media that best fulfill their individual needs. Uses and gratifications theory assumes that the user has alternate choices to satisfy their need. The theory focuses more attention on the audience, rather than on the actual message itself by asking "what people do with media" rather than "what media does to people". The theory regards the audience as very active and not passive thus they have the discretion in determining their choices of the media based on their expectation. The theory is significant to this study, because the work examines the pattern of social media usage by the students.

\subsection{Literature Review}

People use social network sites for a variety of reasons such as ease of use, sharing the continuously increasing information, establishing and maintaining spontaneous social contacts and relationships, supporting informal learning practices with interaction and communication and facilitating delivery of education (Mazman and Usluel, 2011, Anderson, 2009). Social media are characterized as Web 2.0 resources that emphasize active participation, connectivity, collaboration, and sharing of knowledge and ideas among users. Social media resources can be divided into three distinct categories. While one category emphasizes content sharing and organizing sites like Delicious, Digg, Flickr, YouTube, and RSS readers, the second category encompasses content creation and editing websites such Blogger, Google Docs, Wikipedia, and WordPress. The third category includes social network sites (SNS) like Facebook, Ning, MySpace and Instagram among other, that serve as online communities that enable users to connect with old and new friends, and share ideas and resource (Mcloughlin and Lee, 2007).

Social media are also used by many media houses for information gathering and dissemination. For instance, CNN dedicates a program $i$ Report mainly to stories sourced from the social media. Originally the stories might 
not have been meant directly for CNN. Leach (2009) writes that digital media, and the emerging use of social media, are exponentially expanding the reach of journalism, and this presents the practitioners and the audience, with opportunities and dilemmas.

Leach explains that Journalism's reliance on the tools of social media is evident already through social media users' participation information gathering and dissemination. Consider the coverage of the post-election protests in Iran. With journalists banished or silenced by the Iranian government, news organizations and Web sites relied on showing random snippets of video or text messages or tweets sent from people witnessing the protests on the streets of Tehran. The organization and coverage of the recent revolutions in North Africa and the Middle East (NAME) especially Tunisia, Egypt, Libya, Yemen, Bahrain and Syria illuminate how individual political beliefs and the mass media goals now intersect with social media's tools. However, there is still the question of accuracy and credibility.

The use of the social media is very popular among students. Junco (2011) found that Facebook is the most preferred social media among students. The reasons for their preference are: all their friends/classmates are on Facebook and ease of use. Ito et al. (2008) Curran and Lennon (2011) explain that college students prefer to be connected at all times to their friends and family through social media. Social media encourage genuine feedback among the students, thus the social media encourage the formation of users' community. Users benefit enormously from news prompting and contributions from the social media subscribers. (Picard, 2009; Gordon,2009, Hagerty, 2009, Alkan and Bardakci (2017).

Corroborating the above view, MacMillan (2009) explains that the social media connect the users to all parts of the world where social media subscribers actively exist. Contrarily, Palfreman (2009) fears the growth and popularity of the social media and the likely effect on the law and ethics guiding public communication. Palfreman observes that the activities of the social media can have serious negative consequence on conventional practices in the society. Many people connect to social network sites daily and use the social media to connect to different people and groups for different purposes. The purpose of such social media connections varies (Joinson, 2008; Lenhart, 2009, Arouri 2015). However, many of the people who use the social media are students of higher institutions of learning (Manca and Ranieri 2016, Akakandelwa and Walubita, 2018, Dumpit and Fernandez, 2017).

Nandez and Borrego (2013) in their study of the use of social networks for academic purposes by students found that in addition to academic use, students use the social media for various other purposes. The students use the social media to do their assignments, carry out researches, communicate among themselves and communicate with their lecturers. The findings of Tartari (2015) corroborated the finding of Nandez and Borrego. Tartari found that students in institutions of higher learning use the social media for different purposes. They use the social media to supplement what they are taught in the conventional classroom. They also use them for entertainment, social connections and social engagements. Students have much interest in the use of the social media. The question which many researchers try to answer is the proportion of the usage dedicate to academic purpose. Erkan and Huseyin (2017) found in their study on the purpose of students' social media use and determining their perspectives on education, that students use the social media to source information for academic purpose, use the social media to share academic information among themselves, use them to interact academically with their lecturers and use the social media to improve the cooperative learning with other students. Many studies have shown that apart from using the social media for academic purpose, students use them for several other purposes. For instance, Lenhart and Madden (2009) found that students use the social media to communicate with their friends regularly. Akindehin and Akindehin (2011) also found that students use the social media significantly for entertainment. They use them to play music, watch movies, play games and engage in other types of entertainment

Studies have shown that students spend considerable quantum of their time using the social media. Findings by Kaufman and Christakis (2008), Abramson (2011), Muthui \& Sirera (2017) show that on daily basis students spend much of their time using the social media. Findings from a study by Alnjadat, Hmaidi, Samha, Kilani and Hasswan (2019) on gender variations in social media usage and academic performance among the students of University of Sharjah, showed that the students spend between $2-3$ hours daily on the social media. The students use much of their time using the social media for different reasons. Some of them spend their time on the social media for academic purpose while others use them for different reasons such as entertainment, online window shopping and actual shopping, making friends, communicating with friends, fellow students and family members, and several other purposes.

Rutherford (2010) found that students use the social media frequently. In different studies by Heiberger and Harper (2008), Tufekci, (2008) Sultan and Christian (2014), found positive correlation between social media use and college students engagement. Underwood, Kerlin and Farrington-Flint (2011) explain that using social media like Facebook and Twitter have become part and parcel of modern adolescence. $90 \%$ of all American teens have used social media, three-quarters of them have a social net-working site, and nearly one in three teens visits their social networking profile several times a day or more. These young users who are also students have positive perception of the social media. Ito, et al (2010) and Turkle (2011), established positive relationship between social media use and their perception of the social media. Smith and Caruso (2010) found that the use Facebook among 
college students has increased in the past few years.

People of different ages use the social media for different purposes. However, studies have shown that university students seem to use the social media more than other age groups (Miller and Melton, 2015).

Smith and Caruso (2010) and Meşe1 and Aydın (2019) maintain further that different people use the social media for different purposes. Some of these purposes are productive and positive while others are negative. They also found out in their study that there is significant relationship between the users' perception and his usage of any information and communication technology, including the social media. The implication is that those who have positive perception of the social media are more likely to use the social media than those who have negative perception of the social media.

Aiyebelehin and Omekwu (2019) explain that students, librarians and members of the university community in Nigeria have positive perception of the social media. They predicated this perception on the ease of use and the usefulness of the social media. Aleksandrova and Parusheva (2019) also found that students in higher institutions of learning have positive perception of the social media and they use. Dumpit and Fernandez (2017) also found a correlation between perception and ease of use subjective norm and perceived playfulness and use of the social media by students in institutions of higher learning.

Many studies have shown a strong relationship between perception and students' use of the social media. For instance, Alamri (2019) conducted a study on undergraduate students' perceptions toward social media usage and academic performance among students in Saudi Arabia and found significant relationship between perception and students' social media use. The students were found to have positive perception of the social media and they actually use the social media for different purpose. Elsaadani (2012) and Al-Zahrani (2015) also found significant relationship between perception and students' use of the social media.

Students have very favourable perception of the social media. Different studies have been conducted to ascertain how students perceive the social media. Most, if not all, of such studies indicate that students perceive the social media favourably. They regard them as functional and credible companions and tools for performing several functions. Some of such studies include the ones by Thompson and Lougheed (2012), and Chen \& Bryer (2012), Alshareef (2013), Neier and Tuncay (2015), Al-Sharqi \& Hashim (2016). They found in their different studies that students have favourable perception of the social media.

Rutherford (2010) found social media to be very useful to students in their learning, social relations and other fields of human endeavours. As a result, the students have positive perception of the social media and they use them for different purpose. Their usage of social media range from scholarship, social connections and relationship, games and entertainment, entrepreneurship, marketing, cultural projection, talent exhibition, among several other uses. Rutherford also found out that the students use the social media very frequently.

On the relationship between gender and social media usage, Hargittai (2007) found that gender plays significant role in the use of the social media. The finding indicated that more women than men use the social media. The findings of Joinson (2008) corroborate those of Hargittai which indicated that women are more likely to use the social media such as Facebook or MySpace while the male are more likely to use Linkedln. His findings suggest that female users are much more predisposed to social media. The implication of the finding is that there is significant relationship between the social media and the gender of the users.

Junco, Merson, Salter (2010) found a significant relationship between gender and the use of social media by students in the United State of America. Similarly, Guimaraes (2014) found that female users of the social media in the United States of America are more inclined to using Facebook. The study found that women use the social media more than men do. Corroborating the findings Junco et al. (2010) and Guimaraes (2014), Al-Sharqi and Hashim (2016) found a significant correlation between gender and social media usage. Gender seems to play significant role in students' use of the social media. Studies that support this position include those by Abdelraheem (2013), Gok (2015), Alkaabi, Albion and Redmond (2017) and Alnjadat (2019). They found significant correlation between gender and social media usage by students.

Madden and Zickuhr (2011) found that among Internet users, social networking sites are most popular with women. Hampton, et.al. (2011) also found that social networking site users were mainly female. Mazman and Usluel (2011) also found that gender is a significant factor in the use of social media, with more females using the social media. Nicole, et al (2012) found significant relationship between college students' perception and their usage of the social media. They have positive perception of the social media and thus use them adequately and frequently.

In a nutshell, the social media have become adopted by many people who use them for different purposes. Perception and gender may also be important determinant in the usage of the social media. There is also the fear that despite the wide acceptance of the social media, the social media may breed or encourage certain deviance and outright evil in the society.

\subsection{Methods}

The entire population of students in higher institutions of learning in Delta State constituted the population of the 
study. There are approximately 140,000 students in the institutions. The institutions are: Delta State University, Abraka; Novena University, Oguma; University of the Western Delta, Oghara; Michael and Cecilia Ibru University, Agbarha- Otor, Edwin Clark University, Kiagbado, Delta State Polytechnic, Oghara; Delta State Polytechnic, Ogwash-Uku; Delta State Polytechnic, Ozoro; Federal College of Education (Technical), Asaba; College of Education, Agbor; College of Education, Warri; College of Physical Health, Mosogar; College of Health Technology, Ufoma and College of Marine Technology, Burutu. Six thousand students were selected as the sample to represent 6 of the 12 institutions. One thousand respondents were selected from each of the sampled institutions. Two institutions were chosen from each of the three senatorial districts in the state. They are Delta State University, Abraka and Delta State Polytechnic, Oghara (Delta Central); Delta State Polytechnic, OgwashUku and College of Education, Agbor (Delta North); and Delta State Polytechnic, Ozoro and College of Education, Warri (Delta South). The institutions were selected through simple random sampling. The individual samples were selected randomly on the basis of gender equality. Questionnaire was used as the instrument of data gathering. In measuring the reliability of the research instrument, the SPSS version 20 was used and a cronbach alpha reliability of 0.88 was obtained which indicated that the research instrument had a strong reliability. Trained research assistants helped to administer the instrument. Descriptive data analysis was used for the research questions while regression analysis was used to test the hypotheses. A total of 6000 copies of the questionnaire were administered. However, 5382 were returned which accounted for a return rate of $(89.88 \%)$.

The data obtained for the study were analyzed, using quantitative approach. Additionally, we used descriptive statistics for the research questions. On the other hand, regression analysis was used to test correlation between variables in the hypotheses. In the regression analysis we were mainly concerned with $t$ values, $f$ values and beta values. The null hypotheses were tested at 0.05 significance level. To ensure scientific precision and accuracy, the analysis was carried out using SPSS version 20.

\subsection{Findings and Discussion}

Research Question One: "What are the primary purposes for which the students use the social media?" The answer to this research question is addressed in Table 1 below.

Table 1: Distribution of Pattern of Students' Usage of the Social Media

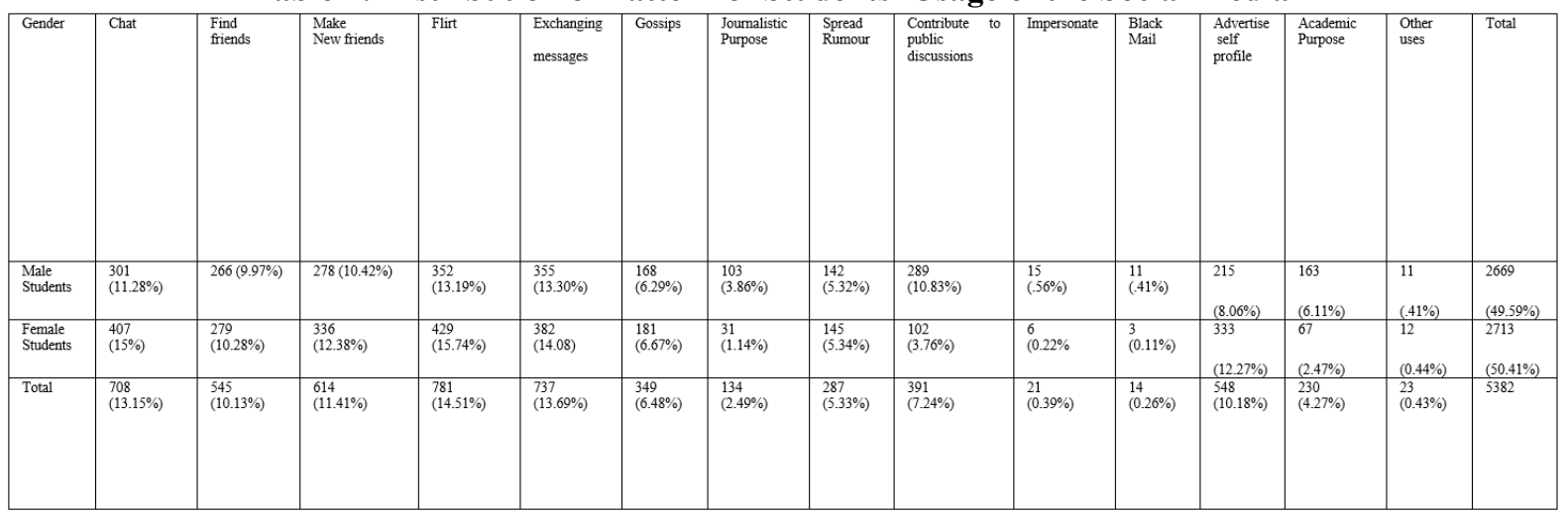

The findings show that $49 \%$ male students use social media while $50.41 \%$ female use social media. The students use social primarily for the following purposes in other of preference: flirting $-14.51 \%$; exchanging message $-13.6 \%$; make new friends $-11.41 \%$; advertise self profile $-10.18 \%$; find friends $-10.13 \%$; contribute to public discussions - 7.24\%; gossips - $6.48 \%$; spread rumour - 5.33\%; academic purpose - 4.27\%; journalistic purpose $-2.49 \%$; other unspecified uses $-0.43 \%$; impersonation $-0.39 \%$; and blackmail $-0.26 \%$. The findings are line with those of Mazman and Usluel (2011); Anderson (2009) which showed that social media users use them for different purposes.

\section{Research Question Two:}

"What are the preferred social media used by the students?" The answer to this research question is addressed in Table 2 below. 
Table 2: Distribution Students' Preference for the Social Media

\begin{tabular}{|c|c|c|c|c|c|c|c|c|c|c|c|c|c|}
\hline Gender & Facebook & Twitter & MySpace & $2 \mathrm{Go}$ & Flickr & Linkedln & $\begin{array}{l}\text { You } \\
\text { tube }\end{array}$ & $\begin{array}{l}\text { My } \\
\text { Life }\end{array}$ & Ibibo & Badoo & Bebo & Others & Total \\
\hline $\begin{array}{l}\text { Male } \\
\text { Students }\end{array}$ & $\begin{array}{l}1221 \\
(45.74 \%)\end{array}$ & $\begin{array}{l}279 \\
(10.45 \%)\end{array}$ & $\begin{array}{l}103 \\
(3.86 \%)\end{array}$ & $\begin{array}{l}372 \\
(6.91 \%)\end{array}$ & $\begin{array}{l}93 \\
(1.73 \%)\end{array}$ & $\begin{array}{l}141 \\
(2.62 \%)\end{array}$ & $\begin{array}{l}269 \\
(5.00 \%)\end{array}$ & $\begin{array}{l}67 \\
(1.24 \%)\end{array}$ & $\begin{array}{l}21 \\
(0.39 \%)\end{array}$ & $\begin{array}{l}62 \\
(1.15 \%)\end{array}$ & $\begin{array}{l}41 \\
(0.76 \%)\end{array}$ & 00 & 2669 \\
\hline $\begin{array}{l}\text { Female } \\
\text { Students }\end{array}$ & $\begin{array}{l}114 \\
(41.06 \%)\end{array}$ & $\begin{array}{l}468 \\
(17.25 \%)\end{array}$ & $\begin{array}{l}45 \\
(1.66 \%)\end{array}$ & $\begin{array}{l}323 \\
(11.91 \%)\end{array}$ & $\begin{array}{l}86 \\
(3.17 \%)\end{array}$ & $\begin{array}{l}216 \\
(7.6 \%)\end{array}$ & $\begin{array}{l}294 \\
(10.84 \%)\end{array}$ & $\begin{array}{l}54 \\
(1.99 \%)\end{array}$ & $\begin{array}{l}17 \\
(0.63 \%)\end{array}$ & $\begin{array}{l}57 \\
(2.10 \%)\end{array}$ & $\begin{array}{l}39 \\
(1.44 \%)\end{array}$ & 00 & 2713 \\
\hline Total & $\begin{array}{l}2334 \\
(43.37 \%)\end{array}$ & $\begin{array}{l}747 \\
(13.88 \%)\end{array}$ & $\begin{array}{l}148 \\
(2.75 \%)\end{array}$ & $\begin{array}{l}695 \\
(12.91 \%)\end{array}$ & $\begin{array}{l}179 \\
(3.33 \%)\end{array}$ & $\begin{array}{l}357 \\
(6.63 \%)\end{array}$ & $\begin{array}{l}563 \\
(10.46 \%)\end{array}$ & $\begin{array}{l}121 \\
2.25 \%)\end{array}$ & $\begin{array}{l}38 \\
(0.71 \%)\end{array}$ & $\begin{array}{l}119 \\
(2.21 \%)\end{array}$ & $\begin{array}{l}80 \\
(1.49 \%)\end{array}$ & 00 & 5382 \\
\hline
\end{tabular}

The findings indicate that the students have the following order of preference for the social media: Facebook (45.74\%); Twitter (10.45\%); $2 \mathrm{G0}$ (6.91\%); YouTube (5.00\%); MySpace (3.86\%); Linkeld (2.62\%); Flickr (1.73\%); MyLife (1.26\%); Badoo (1.15\%); Bebo (0.76\%); and Ibibo (0.39\%) None of the students uses any of the rest 247 social media. They do not have preference for any other social media than the 11 list above. This suggests that the students use only $11(4.38 \%)$ of the 253 social media available worldwide. The findings are line with Junco (2011) findings that suggested that Facebook is the most preferred social media among students.

Research Question Three: How many hours spent daily by the students in using the social media? Table 3: Number of hours spent daily by the students using the social media

\begin{tabular}{|c|c|c|c|c|}
\hline & & Frequency & Percent & Valid Percent \\
\hline \multirow{6}{*}{ Valid } & 1-2 hours daily & 1260 & 23.4 & 23.4 \\
\hline & $3-4$ hours daily & 3225 & 59.9 & 59.9 \\
\hline & 5 - 6 hours daily & 734 & 13.6 & 13.6 \\
\hline & 7 - 8 hours daily & 132 & 2.5 & 2.5 \\
\hline & 8 hours and above daily & 31 & 6 & .6 \\
\hline & Total & 5382 & 100.0 & 100.0 \\
\hline
\end{tabular}

The result in the table above shows that more of the respondents $(59.9 \%)$ spend between $3-4$ hours daily; $23.4 \%$ reported that they use the social media between 1-2 hours daily; and $13.6 \%$ said they use them between 5 -6 hours daily. Meanwhile, $2.5 \%$ and $.6 \%$ of the respondents reported that they use the social media between $7-$ 8 daily and 8 hours daily respectively. This result implies that most of the respondents use the social media between $2-3$ hours daily.

The finding agrees with those of Joinson, (2008); Lenhart, (2009); Rutherford (2010) and Nicole, et al (2012) which indicated that students use social media frequently for different purposes.

Research Question Four: What is the students' perception of the social media?

\begin{tabular}{|ll|l|l|l|}
\hline & Frequency & Percent & Valid Percent \\
\hline \multirow{4}{*}{ Valid } & Positive & 5176 & 96.2 & 96.2 \\
& Neutral & 172 & 3.2 & 3.2 \\
& Negative & 34 & .6 & .6 \\
& Total & 5382 & 100.0 & 100.0 \\
\hline
\end{tabular}

The result indicates that majority of the respondents $(96.2 \%)$ said they have positive perception of the social media. A total of $3.2 \%$ reported having neutral perception about the social media while $.6 \%$ reported having negative perception of the social media. The implication of the finding is that most of the respondents have positive perception of the social media.

The finding is thus in line with the findings of Smith and Caruso (2010) and Nicole, et al (2012) which indicated that people generally have positive perception of the social media.

\section{Hypotheses Testing}

Hypothesis One: There is no significant relationship between gender and the students' usage of the social media. 
Table 5: Relationship and Regression Analysis of Gender and the Students' use of social media

\begin{tabular}{|ll|r|r|r|r|r|}
\hline Model & Sum of Squares & \multicolumn{1}{c|}{ df } & Mean Square & \multicolumn{1}{c|}{ F } & Sig. \\
\hline \multirow{3}{*}{1} & Regression & 48.401 & 1 & 48.401 & 200.756 & $.000^{\mathrm{b}}$ \\
& Residual & 1297.096 & 5380 & .241 & & \\
& Total & 1345.497 & 5381 & & & \\
\hline
\end{tabular}

a. Dependent Variable: Gender of the respondents

b. Predictors: (Constant), Usage of the social media by the respondents

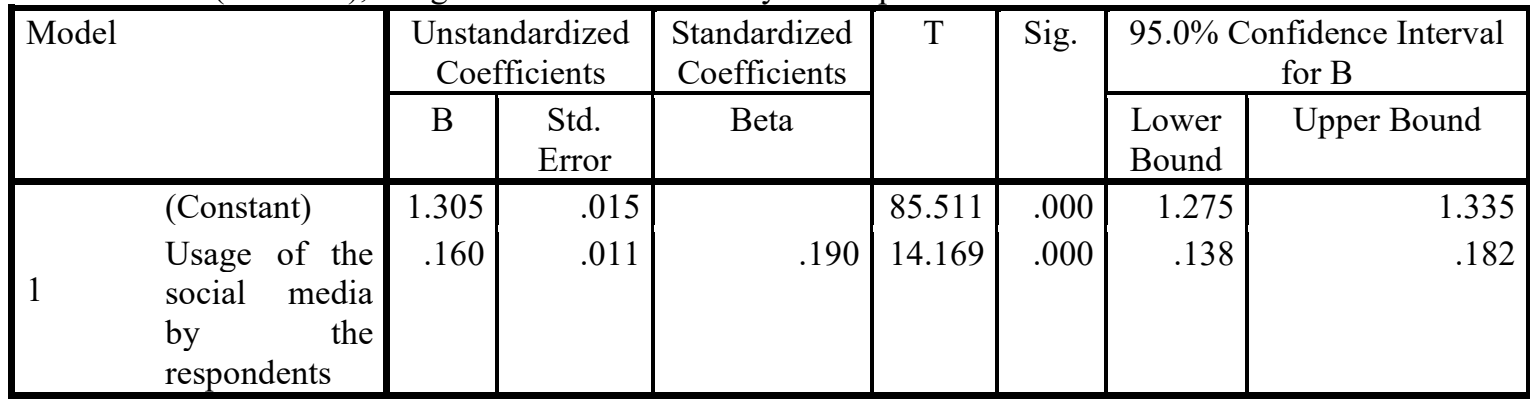

The t test output of 85.511 and 14.169 are very significant at $1 \%$ level of significance. The size of the standard error (.015 and .011) is very significantly small implies that our result is very robust and the t value also validates the high level of significance of the result. The constant is positive and significant at $1 \%$ which means that apart from the gender of the respondents there are other factors that contributed to the high level of significance obtained by this study. Furthermore the Beta (0.190) implies that there is a significant correlation between gender (either male or female) and social media usage by the respondents. The overall $\mathrm{F}$ critical (200.756) which is significant at $1 \%$ is an indication of the overall goodness of the overall model. Finally, the null hypothesis which states that there is no significant relationship between gender and the students' usage of the social media is not rejected. The findings are in line with the findings of Hargittai (2007), Joinson (2008), Madden and Zickuhr (2011), Hampton et.al. (2011) and Mazman and Usluel (2011) whose findings indicate that there is significant relationship between gender and social media usage.

Hypothesis Two: There is no significant relationship between the students' perception and their use of Social media

Table 6: Relationship and Regression Analysis of the Students' Perception of Social Media and their Usage of Social Media.

\begin{tabular}{|rl|r|r|r|r|r|}
\hline \multicolumn{1}{|c|}{ Model } & & ANOVA & \multicolumn{1}{c|}{ F } & Sig. \\
\hline \multirow{2}{*}{1} & Regression & Sum of Squares & \multicolumn{1}{c|}{ Df } & Mean Square & \multicolumn{1}{c|}{ F } \\
& Residual & 30.735 & 1 & 30.735 & 620.329 & $.000^{\mathrm{b}}$ \\
& Total & 266.562 & 5380 & .050 & & \\
\hline
\end{tabular}

a. Dependent Variable: Students' perception of Social Media

b. Predictors: (Constant), Social media usage by students

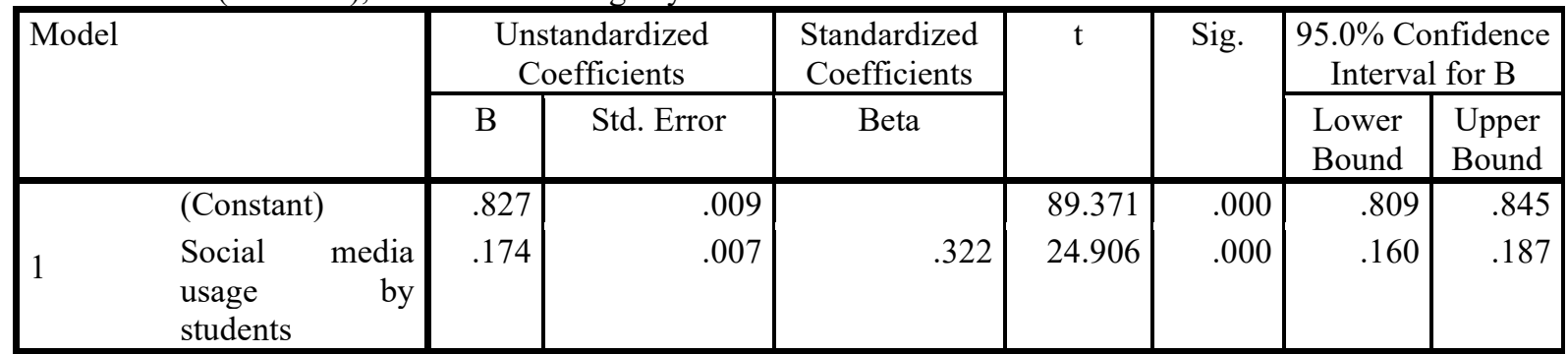

The $t$ test outputs of 89.371 and 24.906 are very significant at $1 \%$ level of significance. The size of the standard error (.009 and .007) is very significantly small implies that the result is very good and the t value (89.371 and 24.906) also validates the high level of significance of the result. The constant (students' perception of the social media) is positive and significant at $1 \%$ which means that apart from the gender of the respondents there are other factors that contributed to the high level of significance obtained by this study. Furthermore the Beta $(.322)$ implies that there is a significant correlation between gender (either male or female) and social media usage by the respondents. The overall $\mathrm{F}$ critical (620.329) which is significant at $1 \%$ is an indication of the overall goodness of the overall model. Therefore, the null hypothesis which states that there is no significant relationship between perception and the students' usage of the social media is not rejected. 
The finding is in line with the finding of Nicole, et al (2012) which suggests that there is significant relationship between perception and social media use.

\subsection{Summary}

The social media have become very important in both interpersonal and mass communication globally. The students in the institutions of higher learning in Delta State of Nigeria are adequately exposed to the social media and they use them frequently, though they are exposed to only $4.38 \%$ of the 253 social media. The students also have positive perception of the social media and use them for different purposes. There is significant correlation between gender and the students' usage of the social media. Furthermore, there is significant relationship between the students' perception of the social media and their usage of the social media.

\subsection{Conclusion}

The study set out to investigate the students' pattern of social media usage. Five research questions were used to seek answers to the research problem. We used both parametric and non-parametric data analysis for the research questions and the hypothesis respectively. Based on the findings, we could conclude that the students in institutions of higher learning in Delta state use the social media extensively for different purposes which range from academic, entertainment, social interactions and engagement to commerce.

Additionally, we found that the students spend good number of hours daily using the social media. We also concluded that the students have very favourable perception of the social media and this favourable perception has a significant positive correlation with their usage of the social media. In essence, they use the social media significantly. Additionally, we could conclude from the study that there is a significant correlation between gender and media usage among students of higher institutions learning in Delta State.

\subsection{Recommendations}

The students should be encouraged by their lecturers and the appropriate authorities to get exposed to more of the social media which serve other important purposes in addition to the ones they are already hooked to. The authorities of the institutions should formulate and implement functional ICT policies and enlighten the students to use the social media for positive and productive purposes. The students should also be encouraged by their institutions and the appropriate government departments to channel their use of the social media to better and more productive purposes. The authorities of the institutions, information technology (IT) bodies, the mass media and the government should organize awareness campaigns on the use of the social media in order to encourage the students to get more exposed to the social media and to use them more positively and productively.

\section{References}

Abdelraheem, A. Y. (2013, 14-16 January 2013). University students' use of social networks sites and their relation with some variables. Paper presented at the WEI International Academic Conference, Antalya, Turkey.

Abramson, L. (2011). Can social networking keep students in school? NPR: Morning Edition, Retrieved October 21, 2019, from http://www.npr.org/2011/02/09/133598049/can-social-networking-keep-students-in-school

Adomi, E.E. (2006). "Mobile Phone Usage Patterns of Library and Information Science Students at Delta State University, Abraka, Nigeria.

Aiyebelehin, A.J. and Omekwu, O.C (2019). Perception as predictor of social media utilization by librarians in universities in Southern Nigeria. Library Philosophy and Practice - Electronic Journal

Akakandelwa, A. and Walubita, G (2018). Students' Social Media Use and its Perceived Impact on Students' Social Media Use and the Perceived Impact on their Social Life: A Case Study of the University of Zambia. The International Journal of Multi-Disciplinary Research

Akindehin, F. and Akindehin, M. (2011).Online social networking practices of some Nigerian university undergraduates: Implications for counseling. British Journal of Arts and Social Sciences, 3(1), 68-78.

Alamri, M.M. (2019). Undergraduate students' perceptions toward social media usage and academic performance: A Study from Saudi Arabia. International Journal of Emerging Technologies in Learning, 14(3), 61-79

Alkaabi, S, Albion, P, Redmond, P. (2017). Social network misuse in the classroom and its impact on male student motivation in UAE tertiary education. IAFOR Journal of Education 5(SI), 115-131

Alkan MF, Bardakci S (2017). High School Students' Learning Activities through Social Networks: A Qualitative Inquiry. Kastamonu Education Journal 25(3):1221-1238.

Alshareef, M. (2013). Evaluate student satisfaction for social learning network at King Abdulaziz University. Advances in Internet of Things, 3, 41-44.

Al-Sharqi, and Hashim, K. (2016). University students' perceptions of social media as a learning tool. The Journal of Social Media in Society 5(1), 65-88

Al-Zahrani, A. M. (2015). From passive to active: The impact of the flipped classroom through social learning platforms on higher education students' creative thinking. British Journal of Educational Technology, 46(6), 
1134-1150.

Anderson, T. H.C. (2009). College students say Facebook is the only social networking site that really matters. (Online) Available: www.prweb.com/release s/2009/12/prweb3301654.htm. (November 23, 2019)

Arouri, Y. (2015). How Jordanian University Students Perceive the Opportunities and Challenges of Using Facebook as a Supplementary Learning Resource? International Journal of Emerging Technologies in Learning (10) 1, 46-54.

Blumler J.G. and Katz, E. (1974). The uses of mass communications: Current perspectives on gratifications research. Beverly Hills, CA: Sage. CHI 2008 Proceedings: 1027-1036. Computers in Human Behavior, 27(5), 1621-1626.

Curran, J, \& Lennon, R. (2011). Participating in the Conversation: Exploring ad option of Online Social Media Networks. Academy of Marketing Studies Journal 15(1), 2 1-38.

Dedanne, S.J. (2009). "The Social Media in the Mass Media" A paper presented at a seminar in University of South Florida, St. Petersburg (08/11/09)

Dumpit, D.Z., Fernandez, C.J. (2017). Analysis of the use of social media in higher education

Institutions (HEIs) using the Technology Acceptance Model. International Journal of Educational Technology in Higher Education 14 (5). 1 - 16.

Eid, M. I., \& Al-Jabri, I. M. (2016). Social networking, knowledge sharing, and student learning: The case of university students. Computers \& Education, 99, 14-27.

Elsaadani, M. (2012). Exploration of teaching staff and students' preferences of information and communication technologies in private and academic lives. International Journal of Computer Science Issues, 9(2), 396-402.

Erkan, B. and Huseyin, B. (2017). The purpose of students' social media use and determining their perspectives on education. Procedia Computer Science, 120 177-181

Ford, R. \&Ravansar, H. (2017) CPD 12 Impact Skills 3 -Social Media for Academics: Research Dissemination. (Online) Available: http://www.staffnet.manchester.ac.uk/employment/training/personaldevelopment/academic-staff/. (November 23, 2019)

Gok T. (2015). The effects of social networking sites on students' studying and habits. International Journal of Research in Education and Science, 2(1): 85-93

Guimaraes, T. (2014). Revealed: The demographic trends for every social network. Retrieved from http:// www.businessinsider.com/2014-social-media

Hagerty, V. (2009). Reporting Relies on Questions: Now they Come From Readers. (Online). Available: http://.www.niemam.harvard.edu/reportsitem.aspen. (November 23, 2019)

Hampton, K. N., Goulet, L.S., R ainie, L. \& Purcell, K. (June 16, 2011). Social N etworking sites and our lives. from http://pewinternet.org/reports/2011/Techno logy-and-scial-networks.aspx

Hargittai, E. (2007). Whose space? Differences among users and non-users of social network sites. Journal of Computer-Mediated Communication 13 (1).

Heiberger, G., \& Harper, R. (2008). Have you Facebooked Astin lately? Using technology to increase student involvement. In R. Junco, \& D. M. Timm (Eds.), Using emerging technologies to enhance student engagement. New Directions for Student Services, Issue 124 (pp. 19-35). San Francisco, CA: Jossey-Bass.

Hu Y, Manikonda L, Kambhampati S (2014). What we Instagram : a first analysis of Instagram photo content and user types. Proceedings of the Eight International AAAI Conference on Weblogs and Social Media. 595-598

Institutions (HEIs) using the Technology Acceptance Model. International Journal of Educational Technology in Higher Education 14 (5). 1 - 16.

Ito, M., Baumer, S., et al. (2010). Hanging out, messing around, and geeking out: Kids living and learning with new media. Cambridge, MA: MIT Press.

Ito, M., Horst, H., Bittanti, M., B oyd, D., Herr-Stephenson, B., Lange, G., Pascoe, D.J., \& Robinson, L. (2008). Living and learning with new media; Summary of the findings from the digital youth project. Chicago: The John D. and Catherine T. MacArthur Reports on Digital Media and Learning. Http://www.macfound.or $\mathrm{g} /$ site/apps/nlnet/content3.aspx?c=lkLXJ8MQKrH\&b=6480257 \&ct=6355113

Joinson, A. N. (2008). 'Looking at', 'Looking up' or 'Keeping up with' people? Motives and uses of Facebook". CHI 2008 Proceedings: 1027-1036.

Junco (2011) "Social Media in Higher Education". Retrieved on November 20, 2019 from http://blog.reyjunco.com/college-students-prefer-to-use-facebook-in-their-courses.

Junco, R., Merson, D., \& Salter, D. W. (2010). The effect of gender, ethnicity, and income on college students' use of communication. Cyberpsychology, Behavior and Social Networking, 13(6).

Kaplan, A.M. \& Haenlein, M. (2010).Users of the world, unite! The challenges and

Leach, J. (2009) Creating Ethical Bridges from Journalism to Digital News. (Online) Available: http://.www.niemam.harvard.edu/reportsitem.aspen. (November 20, 2019)

Lenhart, A. \& Madden, M. (2009), Social networking \& teens. Retrieved October 20, 2019 from http://www.pewinternet.org/Reports/2009/TeensPrivacy-and-Online-Social- Networks.aspx 
Lewis, K, Kaufman, J and Christakis, N. (2008). The taste of privacy: An Analysis of college students ${ }^{\text {ee }}$ privacy settings in an online social network. Journal of Computer Mediated Communication 141, 79-100.

MacMillan, J. (2009). “A Photographer's Journey: From Newspaper to Social Media”. (Online) Available: http://.www.niemam.harvard.edu/reportsitem.aspen (November 20, 2019)

Madden, M. \& Zickuhr, K. (2011). “65\% of online adults use social networking sites". (Online) Available: http://pew internet.org/reports/2011/social-networking-sites.aspx (November 21, 2019)

Manca, S. \& Ranieri, M. (2016). Facebook and the Others. Potentials and obstacles of social

media for teaching in higher Education, Computers and Education (95), 216-230.

Mazman, S.G. and Usluel (2011). "Gender Differences in Using Social Networks" The Turkish Online Journal of Educational Technology, 10 (2)

McLoughlin, C., and Lee, M. J. W. (2007). "Social software and participatory learning: Pedagogical choices with technology affordances in the Web 2.0 era". Paper presented at the Australasian Society for Computers in Learning in Tertiary Education Singapore.

Meşe1, C. and Aydın, G.S. (2019). The Use of Social Networks among University Students. Educational Research and Reviews 14(6), 190-199.

Miller R, Melton J (2015). College students and risk-taking behaviour on Twitter versus Facebook. Behaviour and Information Technology 34(7):678-684.

Muthui, E.W and Sirera A.M. (2017). Implications of time spent on social media on academic performance by adolescents in public day secondary schools in Nakuru East Constituency, Kenya. IOSR Journal Of Humanities And Social Science, (22) 11, 27-36

Nandez, G. and Borrego, A. (2013). Use of social networks for academic purposes: A case study. The Electronic Library 31(6) 781-791

Neier, S. and Tuncay, L. (2015). Students' perceptions and experiences of social media in higher education. Journal of Marketing Education 37(3)

Nicole E. H, Gregory S. M, Christen L. B, Lincoln R. L, Matthew D. L, and Luanna B. P. (2012). The 'Facebook' Effect: College Students' Perceptions of Online Discussions in the Age of Social Networking. International Journal for the Scholarship of Teaching and Learning, 6 (2)opportunities of social media. Business Horizon, $53(1), 59-68$.

Palfreman, J. (2009). "Dealing with Disruption". (Online) Available: http://.www.niemam.harvard.edu/reportsitem.aspen. (November 20, 2019)

Picard, R. (2009). "Blogs, Tweets, Social Media, and the News Business". Retrieved 21 November, 2019 http://.www.niemam.harvard.edu/reportsitem.aspen. 09/11/0

Rutherford, C. (2010). "Using Online Social Media to Support Pre-service Student Engagement" MERLOT Journal of Online Learning and Teaching, 6 (4)

Salaam , M.O. (2003). A Survey of the Use of Internet Services by Nigerian University Libraries. ASSERTS Series A, 13 (3) 115-121

Smith, S.D., and Caruso, J.B. (2010). "What are Students doing with Technology" ECAR Study of Undergraduate Students and Information Technology. 6. Boulder, CO: EDUCAUSE Center for Applied Research. (Online) Available: http://net.educause.edu/ir/library/pdf/ers1006/rs/ers1006w. (November 22, 2019)

Sultan, A. \& Christian, B. (2014). Impact of Social Media on Personality Development. International Journal of Innovation and Scientific Research, 3 (2), 111-116.

Tartari, E. (2015). The use of social media for academic purposes in student' learning process. Academic Journal of Interdisciplinary Studies, 4(2), 387-392

Thompson, S. H., \& Lougheed, E. (2012). Frazzled by Facebook? An exploratory study of gender differences in social network communication among undergraduate men and women. College Student Journal, 46(1), 8898.

Tsai TH, Chang HT, Chang YC, Chang YS (2017). Personality disclosure on social network sites: An empirical examination of differences in Facebook usage behavior, profile contents and privacy settings. Computers in Human Behavior (76) 469-482.

Tufekci, Z. (2008). Grooming, Gossip, Facebook and Myspace. Information, Communication \& Society, 11(4), 544-564

Turkle, S. (2011). Alone together: Why we expect more from technology and less from each other. New York: Basic Books.

Underwood, J. D. M., Kerlin, L., \& Farrington-Flint, L. (2011). The lies we tell and what they say about us: using behavioural characteristics to explain Facebook activity.

Yanka Aleksandrova and Silvia Parusheva (2019). Social Media Usage Patterns in Higher Education Institutions - An Empirical Study. International Journal of Emerging Technologies in Learning (14). 5. 108 - 121. 


\section{Acknowledgements}

I personally funded this research. However, there are people who assisted me in different ways during the course of the research. I particularly thank Dr. Emmanuel Akpoveta of the Department of Mass Communication, Delta State Polytechnic, Ogwash -Ukwu, Nigeria, the undergraduate students of mine who participated in the administration of the instrument and the research assistants who helped in the administration of the instrument. 